NLP COVID-19, Schöning (2021)

\title{
1 Automatic identification of risk factors for SARS-CoV-2 2 positivity and severe clinical outcomes of COVID-19 using Data 3 Mining and Natural Language Processing

5 Authors: Verena Schöning ${ }^{1}$, Evangelia Liakoni ${ }^{1}$, Jürgen Drewe ${ }^{2}$, Felix 6 Hammann ${ }^{1, *}$

8 (1) Clinical Pharmacology and Toxicology, Department of General Internal 9 Medicine, Inselspital, Bern University Hospital, University of Bern, Bern, 10 Switzerland

11 (2) Department of Clinical Pharmacology, University Hospital Basel, Basel, 12 Switzerland

14 * Corresponding Author:

15 Felix Hammann, MD, PhD

16 Clinical Pharmacology and Toxicology, Department of General Internal 17 Medicine, Inselspital, Bern University Hospital, Freiburgstrasse, 3010 Bern, 18 Switzerland

19 Felix.Hammann@insel.ch

20

21 Keywords

22 SARS-CoV-2, COVID-19, risk factors, electronic health records, natural 23 language processing 
medRxiv preprint doi: https://doi.org/10.1101/2021.03.25.21254314; this version posted March 26, 2021. The copyright holder for this preprint (which was not certified by peer review) is the author/funder, who has granted medRxiv a license to display the preprint in perpetuity.

It is made available under a CC-BY-NC-ND 4.0 International license .

NLP COVID-19, Schöning (2021)

\section{ABSTRACT}

27 Objectives: Several risk factors have been identified for severe clinical

28 outcomes of COVID-19 caused by SARS-CoV-2. Some can be found in

29 structured data of patients' Electronic Health Records. Others are included as

30 unstructured free-text, and thus cannot be easily detected automatically. We

31 propose an automated real-time detection of risk factors using a combination

32 of data mining and Natural Language Processing (NLP).

33 Material and methods: Patients were categorized as negative or positive for

34 SARS-CoV-2, and according to disease severity (severe or non-severe COVID-

35 19). Comorbidities were identified in the unstructured free-text using NLP.

36 Further risk factors were taken from the structured data.

37 Results: 6250 patients were analysed (5664 negative and 586 positive; 461

38 non-severe and 125 severe). Using NLP, comorbidities, i.e. cardiovascular and

39 pulmonary conditions, diabetes, dementia and cancer, were automatically

40 detected (error rate $\leq 2 \%$ ). Old age, male sex, higher BMI, arterial hypertension,

41 chronic heart failure, coronary heart disease, COPD, diabetes, insulin only

42 treatment of diabetic patients, reduced kidney and liver function were risk

43 factors for severe COVID-19. Interestingly, the proportion of diabetic patients

44 using metformin but not insulin was significantly higher in the non-severe

45 COVID-19 cohort $(p<0.05)$.

46 Discussion and conclusion: Our findings were in line with previously reported

47 risk factors for severe COVID-19. NLP in combination with other data mining

48 approaches appears to be a suitable tool for the automated real-time detection

49 of risk factors, which can be a time saving support for risk assessment and 
medRxiv preprint doi: https://doi.org/10.1101/2021.03.25.21254314; this version posted March 26, 2021. The copyright holder for this preprint (which was not certified by peer review) is the author/funder, who has granted medRxiv a license to display the preprint in perpetuity. It is made available under a CC-BY-NC-ND 4.0 International license.

NLP COVID-19, Schöning (2021)

50 triage, especially in patients with long medical histories and multiple

51 comorbidities. 
medRxiv preprint doi: https://doi.org/10.1101/2021.03.25.21254314; this version posted March 26, 2021. The copyright holder for this preprint (which was not certified by peer review) is the author/funder, who has granted medRxiv a license to display the preprint in perpetuity.

It is made available under a CC-BY-NC-ND 4.0 International license .

NLP COVID-19, Schöning (2021)

\section{BACKGROUND}

53 Coronavirus disease 19 (COVID-19) is caused by the severe acute respiratory

54 syndrome coronavirus 2 (SARS-CoV-2). It was first identified in Wuhan, China,

55 in December 2019,(1) and spread globally with rising numbers of cases and

56 deaths.(2)

57 Several risk factors have been identified for severe COVID-19 disease and

58 need to be taken into consideration when assessing patients in the early stages

59 since they can affect the clinical outcome and are therefore important for patient

60 triage and management decisions. Some of the reported risk factors, such as

61 age,(3, 4) sex, $(5,6)$ or obesity, $(7-10)$ are included in tabulated form in the

62 electronic health records (EHRs). However, information on other relevant

63 comorbidities such as diabetes,(11-13) cardiac(14-16) and pulmonary

64 diseases,(17, 18) cancer,(19) or dementia(20) is usually included as free-text

65 in the medical history of the EHR and can be time consuming to retrieve. This

66 holds in particular in patients with a long medical history and conditions that

67 might not be included separately in the list of diagnoses (e.g. pre-diabetes).

68 Encoding into ICD (International Classification of Diseases) identifiers - which

69 would be highly suitable for machine processing - is often performed only after

70 discharge or death of the patient and is thus not readily available for the risk

71 evaluation on admission, requires human intervention, and might also only

72 include the main diagnoses relevant to billing purposes.

73 Here we propose a real-time support for patient triage by automatically

74 identifying relevant risk factors for infection with SARS-CoV-2 and for the

75 development of severe COVID-19 (i.e. need for critical care, mechanical 
medRxiv preprint doi: https://doi.org/10.1101/2021.03.25.21254314; this version posted March 26, 2021. The copyright holder for this preprint (which was not certified by peer review) is the author/funder, who has granted medRxiv a license to display the preprint in perpetuity.

It is made available under a CC-BY-NC-ND 4.0 International license .

NLP COVID-19, Schöning (2021)

76 ventilation support, or death of any cause). A combination of data mining and

77 natural language processing (NLP) was used to analyse different parts of the

78 EHRs. Structured (tabulated) administrative, demographic and laboratory data

79 as well as unstructured (free-text) medical history information were processed

80 to identify specific risk factors (age, sex, high BMI, diabetes, cardiovascular

81 disease, pulmonary disorders, dementia, cancer, and decreased kidney and

82 liver function) for SARS-CoV-2 infection or severe courses of COVID-19.(15-

$8317,21,22)$ Furthermore, for diabetic patients, the treatment regimen (untreated,

84 insulin, oral anti-diabetics (OAD) or combination of insulin and OAD) on

85 admission was taken into consideration to classify disease severity.

86 After development and internal validation, these methods were used in a

87 retrospective analysis of patients seen at the Insel Hospital Group (IHG) in

88 Switzerland, a tertiary hospital network and the biggest health care provider in

89 Switzerland with six locations and about 860'000 patients treated per year.

90 Patients who received testing for SARS-CoV-2 at any point during the 'first' and

91 'second' waves of the pandemic in 2020 were included.

\section{METHODS}

\section{$93 \quad 2.1$ Study population}

94 The study was carried out at the IHG. The protocol was approved by the

95 Cantonal Ethics Committee of Bern (Project-ID 2020-00973). We considered

96 all individuals tested for SARS-CoV-2 at the IHG between February $1^{\text {st }}$ through

97 November $16^{\text {th }} 2020$ - covering the 'first wave' and part of the 'second wave' of

98 COVID-19 in the country, and who did not reject the IHG general research 
medRxiv preprint doi: https://doi.org/10.1101/2021.03.25.21254314; this version posted March 26, 2021. The copyright holder for this preprint (which was not certified by peer review) is the author/funder, who has granted medRxiv a license to display the preprint in perpetuity.

It is made available under a CC-BY-NC-ND 4.0 International license .

NLP COVID-19, Schöning (2021)

99

100

101

102

103

104

105

106

107

108

109

110

114

115

116

117

118

119

120

121

consent. For patients with no registered general research consent status, a waiver of consent was granted by the ethics committee. Patients who objected to the general research consent of the IHG were excluded from the study. Participation in other trials (including COVID-19 related treatment studies) was not an exclusion criterion and was not recorded separately. A reversetranscriptase polymerase chain reaction (RT-PCR) assay on nasopharyngeal swabs was in use throughout the entire observational period as diagnostic test for SARS-CoV-2 detection. Detailed information on the selection of the study population is provided in Figure 1. All patients had been discharged or died by the time of the analysis.

Patients were classified according to their test result and disease severity, with the worst outcome at any point determining the class:

- Negative: Patients who always tested negative for SARS-CoV-2

- Positive: Patients who tested positive for SARS-CoV-2 at any point

- Non-severe: Patients who tested positive for SARS-CoV-2, but were neither admitted to the intensive care unit (ICU) nor died of any cause during their hospital stay.

- Severe: Composite outcome for patients who tested positive for SARS-CoV-2 and required ICU admission at any stage during the disease or died of any cause during their hospital stay.

Given that the study was retrospective and observational, sample sizes were dictated by the dynamics of the pandemic in the greater Bern region. Consequently, no formal power calculations were performed a priori. 
medRxiv preprint doi: https://doi.org/10.1101/2021.03.25.21254314; this version posted March 26, 2021. The copyright holder for this preprint (which was not certified by peer review) is the author/funder, who has granted medRxiv a license to display the preprint in perpetuity.

It is made available under a CC-BY-NC-ND 4.0 International license .

NLP COVID-19, Schöning (2021)

122 The NLP validation dataset consisted of 138 patients, who were tested positive

123 for SARS-CoV-2 during the first wave in Switzerland (February - August 2020)

124 and whose medical history were available. The EHR was screened manually

125 by two of the authors for the following comorbidities of interest: arterial

126 hypertension, chronic heart failure, atrial fibrillation or flutter, coronary heart

127 disease, asthma, chronic obstructive pulmonary disease (COPD), diabetes

128 (including type I, type II and pre-diabetes), dementia (including mild cognitive

129 impairment), and cancer.(15-17, 21, 22)

\section{$130 \quad$ 2.1.1 Data mining and Natural Language Processing}

131 Age and sex were taken directly from the structured parts of the EHR. Although

132 BMI was also included in the structured parts, some values were not correctly

133 calculated. Therefore, BMI were recalculated using weight and height, which

134 are also documented in the EHR, after removing highly unrealistic values (e.g.

135 weight of $80 \mathrm{~kg}$ for a $<1$ year old child or height of $16.3 \mathrm{~cm}$ for an adult), which

136 were probably due to typing errors. Laboratory values indicative for kidney

137 failure (estimated glomerular filtration rate (GFR) according to the Chronic

138 Kidney Disease Epidemiology Collaboration (CKD-EPI) equation) or hepatic

139 dysfunction (alanine aminotransferase (ALAT) and alkaline phosphatase (AP))

140 were also taken from the structured parts of the EHR. We used the lowest and

141 highest values measured, respectively, in the time frame between three days

142 before and one day after the Sars-CoV-2 test as described in a previous

143 study.(23) Kidney function was categorized into five stages: normal

144 (GFR $\geq 90 \mathrm{~mL} / \mathrm{min}$ ), mild impairment (GFR 60-89 mL/min), moderate

145 impairment (GFR 30-59 mL/min), severe impairment (GFR 15-29 mL/min) and

146 kidney failure (GFR $<15 \mathrm{~mL} / \mathrm{min}$ ).(24) Liver function was considered as 
medRxiv preprint doi: https://doi.org/10.1101/2021.03.25.21254314; this version posted March 26, 2021. The copyright holder for this preprint (which was not certified by peer review) is the author/funder, who has granted medRxiv a license to display the preprint in perpetuity. It is made available under a CC-BY-NC-ND 4.0 International license .

NLP COVID-19, Schöning (2021)

147 impaired if $A L A T>90 \mathrm{U} / \mathrm{L} \quad(\sim 3 \mathrm{x}$ ULN (upper limit of normal)) and/or 148 AP $>200 \mathrm{U} / \mathrm{L}(\sim 2 x \mathrm{ULN})$.

149 The comorbidities of interest were identified in the medical history, which is the 150 unstructured, free-text part of the EHR. In a first step, we merged the 151 information of different time points into a single text file per patient and removed 152 duplicate sentences. We then read the text files into Python as data corpus, 153 where we performed the actual NLP (Figure 2). General data cleaning of these 154 files consisted of converting special characters (e.g. umlauts such as 'ä' to 'ae'), 155 setting the whole text to lower case, and removing dates. Then sentences were 156 tokenized, i.e. the text was separated into single (half-) sentences (tokens).

157 Tokens with less than two characters or information related to family history 158 were removed. As the medical history consisted mainly of catch phrases and 159 half-sentences, we decided against a removal of stop words. For each disease, 160 a specific list of key terms was generated, which consisted of common terms 161 (one or more words) and abbreviations used to describe the diseases in 162 German EHR systems. As there are many different terms for the diverse types 163 of cancer, another approach was chosen for this element. We first scanned all 164 EHRs for words containing cancer-specific terms such as 'cancer', 'carcinoma', 165 or 'neoplasia', and created a key terms list. This list was then appended with 166 other common terms and abbreviations for specific types of cancer, for instance 167 'ALL' for acute lymphoblastic leukaemia. For correction of spelling errors and 168 lemmatization, the key terms list was transformed into a dictionary, where each 169 word only appears once. Words within the medical history were replaced with 170 the corresponding word of the dictionary when the similarity threshold of the 171 Levenshtein distance (minimum number of characters required to transform 
medRxiv preprint doi: https://doi.org/10.1101/2021.03.25.21254314; this version posted March 26, 2021. The copyright holder for this preprint (which was not certified by peer review) is the author/funder, who has granted medRxiv a license to display the preprint in perpetuity.

It is made available under a CC-BY-NC-ND 4.0 International license .

NLP COVID-19, Schöning (2021)

172 one word to another) was equal or bigger than $90 \%$. Then, for each token within

173 the medical history, we checked for the presence of the defined key terms. If

174 the key term consisted of more than one word (e.g. 'arterial hypertension'), the

175 algorithm was set to allow up to three words between the single words of the

176 key term. This further reduced the need for removing stop words.

177 If the key term was present, we determined the context of the key term

178 (affirmation or negation) using a German implementation of NegEx.(25) The

179 output of the negation detection was screened, and the negation trigger list

180 appended accordingly where necessary (e.g. 'non-insulin'). In case of an equal

181 or bigger number of affirmed than negated statements, the patient was tagged

182 as 'positive' for the disease. The disease status of each patient as determined

183 by NLP was compared to the manually tagged label. For cases where the

184 automatically detected disease status varied from the manual one, the medical

185 history was screened again, and, if possible, the key term list was corrected

186 accordingly. The NLP detection was considered suitable if the error rate per

187 disease was $\leq 2 \%$.

188 As the structured medication on admission table was not always filled in, we

189 decided to use a combined approach to identify anti-diabetic treatment: we

190 selected individuals which were identified as diabetes patients by NLP and

191 searched the EHR for key terms of treatment with insulin or OADs. We then

192 combined these NLP results with the medication at admission table. If either

193 the NLP or the medication at admission table showed use of insulin and/or

194 OAD, we tagged the patient as receiving that treatment. If the patient received

195 neither, we categorized the patient as 'untreated'. For the subgroup analysis of

196 the OAD only cohort, we were only able to use the recorded medication on 
medRxiv preprint doi: https://doi.org/10.1101/2021.03.25.21254314; this version posted March 26, 2021. The copyright holder for this preprint (which was not certified by peer review) is the author/funder, who has granted medRxiv a license to display the preprint in perpetuity. It is made available under a CC-BY-NC-ND 4.0 International license .

NLP COVID-19, Schöning (2021)

197 admission to identify metformin, the only biguanide marketed in Switzerland, as

198 medical histories and diagnosis lists often do not mention the specific OAD 199 used.

200 Age, sex, BMI, disease status, anti-diabetic treatment and kidney and liver

201 function of all patients with available information were then analysed and 202 stratified according to the cohorts described above.

\subsubsection{Software and statistical tests}

204 NLP was performed in Python (version 3.8.5). The text file corpus was 205 generated using the Natural Language Toolkit (nltk) package (version 3.5).(26) 206 Steps requiring regular expressions (e.g. text cleaning, sentence tokenization, 207 word replacement) were performed using the re package (version 2.2.1). For 208 spelling correction and lemmatization, we used the FuzzyWuzzy package 209 (version 0.18.0) and specific, manually generated keyword lists. Detection of 210 negation was performed using $\operatorname{NegEx}(27)$ in combination with its German 211 implementation.(25)

212 Data wrangling, analysis and visualization was performed in GNU R (version

213 4.0.2, R Foundation for Statistical Computing, http://www.R-project.org, 214 Vienna, Austria). Standard statistics, e.g. Shapiro-Wilk test, Chi square, 215 Fisher's exact test, Wilcoxon rank sum test, were conducted using the stats 216 package (version 4.0.2).

217 Comparisons were performed between a) patients tested negative and positive 218 for SARS-CoV-2 and b) patients with a non-severe and severe clinical 219 manifestation of COVID-19. Statistical significance levels were determined 220 using Wilcoxon rank sum test for non-normally distributed parameters, as 
medRxiv preprint doi: https://doi.org/10.1101/2021.03.25.21254314; this version posted March 26, 2021. The copyright holder for this preprint (which was not certified by peer review) is the author/funder, who has granted medRxiv a license to display the preprint in perpetuity. It is made available under a CC-BY-NC-ND 4.0 International license .

NLP COVID-19, Schöning (2021)

221 confirmed by Shapiro-Wilk test, and the Chi square test or the Fisher's exact

222 test (sample size $\leq 5$ ) for categorical parameters. A p value of $<0.05$ was

223 considered statistically significant.

\section{RESULTS}

225 A total of 6'250 patients tested for SARS-CoV-2 at the IHG during the study 226 period were included and categorized as either SARS-CoV-2 negative $227\left(n=5^{\prime} 664\right)$ or positive $(n=586)$, and - among the latter- as having a non-severe $228(n=461)$ or severe $(n=125)$ clinical outcome. The comorbidities of interest, i.e. 229 arterial hypertension, chronic heart failure, atrial fibrillation or flutter, coronary 230 heart disease, asthma, COPD, diabetes, dementia and cancer, could be 231 automatically detected in the German EHR of the IHG using NLP with an error 232 rate of $\leq 2 \%$ compared to the manually tagged EHR. The results of the 233 validation and the key terms used for each disease are shown in the 234 supplementary material (Table S1 and Table S2).

235 Stratification of patients to the outcome showed that the proportions of patients 236 with old age, male sex, higher BMI, arterial hypertension, or diabetes were 237 significantly higher in the positive SARS-CoV-2 and in the severe COVID-19

238 cohorts (Table 1). Patients with atrial fibrillation or flutter were more likely to be 239 tested negative for SARS-CoV-2, but despite a tendency for more severe 240 clinical manifestations of COVID-19, these results were not significant. The 241 same proportion of patients with coronary heart disease was tested negative 242 and positive for SARS-CoV-2, but with a higher proportion of patients with a 243 severe course. 
medRxiv preprint doi: https://doi.org/10.1101/2021.03.25.21254314; this version posted March 26, 2021. The copyright holder for this preprint (which was not certified by peer review) is the author/funder, who has granted medRxiv a license to display the preprint in perpetuity. It is made available under a CC-BY-NC-ND 4.0 International license .

NLP COVID-19, Schöning (2021)

244 Table 1: Distribution of risk factors as determined by automated analysis 245 of the Electronic Health Records (EHRs)

\begin{tabular}{|c|c|c|c|c|c|c|}
\hline & \multicolumn{3}{|c|}{ Test for SARS-CoV-2 } & \multicolumn{3}{|c|}{ COVID-19 clinical manifestation } \\
\hline & $\begin{array}{l}\text { negative } \\
(N= \\
5,664)\end{array}$ & $\begin{array}{l}\text { positive } \\
(N=586)\end{array}$ & p-value & $\begin{array}{l}\text { non- } \\
\text { severe } \\
(N=461)\end{array}$ & $\begin{array}{l}\text { severe } \\
(N=125)\end{array}$ & p-value \\
\hline $\begin{array}{l}\text { Age (years) } \\
\text { Median (IQR) }\end{array}$ & $\begin{array}{c}63 \\
(39,77)\end{array}$ & $\begin{array}{c}65 \\
(48,77)\end{array}$ & $0.013^{\$}$ & $\begin{array}{c}62 \\
(44,75)\end{array}$ & $\begin{array}{c}69 \\
(59,81)\end{array}$ & $<0.002^{\$}$ \\
\hline $\begin{array}{l}\text { Sex } \\
\text { Female (\%) }\end{array}$ & $\begin{array}{c}2 ’ 650 \\
(46.8 \%)\end{array}$ & $\begin{array}{c}246 \\
(42.0 \%)\end{array}$ & $0.029^{*}$ & $\begin{array}{c}211 \\
(45.8 \%)\end{array}$ & $\begin{array}{c}35 \\
(28.0 \%)\end{array}$ & $<0.002^{*}$ \\
\hline Median (IQR) & $\begin{array}{c}24.6(21.1 \\
28.7)\end{array}$ & $\begin{array}{c}26.5(23.5 \\
29.7)\end{array}$ & $<0.002^{\$}$ & $\begin{array}{l}25.9 \\
(23.2 \\
29.4)\end{array}$ & $\begin{array}{l}27.9 \\
(24.8 \\
30.9)\end{array}$ & $0.003^{\$}$ \\
\hline $\begin{array}{c}\text { Diseases } \\
\text { aHT } \\
(\%)\end{array}$ & $\begin{array}{c}2,270 \\
(40.1 \%)\end{array}$ & $\begin{array}{c}270 \\
(46.1 \%)\end{array}$ & $0.006^{*}$ & $\begin{array}{c}192 \\
(41.7 \%)\end{array}$ & $\begin{array}{c}78 \\
(62.4 \%)\end{array}$ & $<0.002^{*}$ \\
\hline $\begin{array}{l}\text { Chronic heart } \\
\text { failure (\%) }\end{array}$ & $\begin{array}{c}1,591 \\
(28.1 \%)\end{array}$ & $\begin{array}{c}140 \\
(23.9 \%)\end{array}$ & $0.035^{*}$ & $\begin{array}{c}97 \\
(21.0 \%)\end{array}$ & $\begin{array}{c}43 \\
(34.4 \%)\end{array}$ & $0.003^{*}$ \\
\hline $\begin{array}{l}\text { Atrial } \\
\text { fibrillation or } \\
\text { flutter (\%) }\end{array}$ & $\begin{array}{c}1,025 \\
(18.1 \%)\end{array}$ & $84(14.3 \%)$ & $0.027^{*}$ & $\begin{array}{c}59 \\
(12.8 \%)\end{array}$ & $\begin{array}{c}25 \\
(20.0 \%)\end{array}$ & $0.058^{*}$ \\
\hline $\begin{array}{l}\text { Coronary } \\
\text { heart disease } \\
(\%)\end{array}$ & $\begin{array}{c}1,052 \\
(18.6 \%)\end{array}$ & $92(15.7 \%)$ & $0.098^{*}$ & $\begin{array}{c}56 \\
(12.2 \%)\end{array}$ & $\begin{array}{c}36 \\
(28.8 \%)\end{array}$ & $<0.002^{*}$ \\
\hline Asthma (\%) & $350(6.2 \%)$ & $52(8.9 \%)$ & $0.015^{\star}$ & $45(9.8 \%)$ & $7(5.6 \%)$ & $0.203^{*}$ \\
\hline COPD (\%) & $\begin{array}{c}612 \\
(10.8 \%)\end{array}$ & $45(7.7 \%)$ & $0.023^{*}$ & $28(6.1 \%)$ & $\begin{array}{c}17 \\
(13.6 \%)\end{array}$ & $0.009^{*}$ \\
\hline Diabetes (\%) & $\begin{array}{c}1,129 \\
(19.9 \%)\end{array}$ & $\begin{array}{c}155 \\
(26.5 \%)\end{array}$ & $<0.002^{*}$ & $\begin{array}{c}111 \\
(24.1 \%)\end{array}$ & $\begin{array}{c}44 \\
(35.2 \%)\end{array}$ & $0.017^{*}$ \\
\hline Dementia (\%) & $516(9.1 \%)$ & $55(9.4 \%)$ & $0.885^{*}$ & $40(8.7 \%)$ & $\begin{array}{c}15 \\
(12.0 \%)\end{array}$ & $0.339^{*}$ \\
\hline Cancer (\%) & $\begin{array}{c}1,407 \\
(24.8 \%)\end{array}$ & $96(16.4 \%)$ & $<0.002^{*}$ & $\begin{array}{c}73 \\
(15.8 \%)\end{array}$ & $\begin{array}{c}23 \\
(18.4 \%)\end{array}$ & $0.582^{*}$ \\
\hline $\begin{array}{l}\text { Kidney } \\
\text { function }\end{array}$ & & & & & & \\
\hline $\begin{array}{l}\text { Normal, GFR } \\
>90 \mathrm{~mL} / \mathrm{min} \\
(\%)\end{array}$ & $\begin{array}{c}2,131 \\
(36.16 \%)\end{array}$ & $\begin{array}{c}196 \\
(32.13 \%)\end{array}$ & 0.054 & $\begin{array}{c}163 \\
(36.22 \%)\end{array}$ & $\begin{array}{c}33 \\
(20.62 \%)\end{array}$ & $<0.002$ \\
\hline $\begin{array}{l}\text { Mild } \\
\text { impairment, } \\
\text { GFR 60-89 } \\
\text { mL/min (\%) }\end{array}$ & $\begin{array}{c}1,871 \\
(31.74 \%)\end{array}$ & $\begin{array}{c}239 \\
(39.18 \%)\end{array}$ & $<0.002^{*}$ & $\begin{array}{c}187 \\
(41.56 \%)\end{array}$ & $\begin{array}{c}52 \\
(32.50 \%)\end{array}$ & 0.055 \\
\hline $\begin{array}{l}\text { Moderate } \\
\text { impairment, } \\
\text { GFR } 30-59 \\
\text { mL/min (\%) }\end{array}$ & $\begin{array}{c}1,299 \\
(22.04 \%)\end{array}$ & $\begin{array}{c}116 \\
(19.02 \%)\end{array}$ & 0.095 & $\begin{array}{c}77 \\
(17.11 \%)\end{array}$ & $\begin{array}{c}39 \\
(24.38 \%)\end{array}$ & 0.058 \\
\hline
\end{tabular}


medRxiv preprint doi: https://doi.org/10.1101/2021.03.25.21254314; this version posted March 26, 2021. The copyright holder for this preprint (which was not certified by peer review) is the author/funder, who has granted medRxiv a license to display the preprint in perpetuity.

It is made available under a CC-BY-NC-ND 4.0 International license.

NLP COVID-19, Schöning (2021)

\begin{tabular}{|c|c|c|c|c|c|c|}
\hline & \multicolumn{3}{|c|}{ Test for SARS-CoV-2 } & \multicolumn{3}{|c|}{ COVID-19 clinical manifestation } \\
\hline & $\begin{array}{l}\text { negative } \\
(N= \\
\left.5^{\prime} 664\right)\end{array}$ & $\begin{array}{l}\text { positive } \\
(N=586)\end{array}$ & $p$-value & $\begin{array}{l}\text { non- } \\
\text { severe } \\
(N=461)\end{array}$ & $\begin{array}{l}\text { severe } \\
(N=125)\end{array}$ & p-value \\
\hline $\begin{array}{l}\text { Severe } \\
\text { impairment, } \\
\text { GFR 15-29 } \\
\text { mL/min (\%) }\end{array}$ & $\begin{array}{c}385 \\
(6.53 \%)\end{array}$ & $37(6.07 \%)$ & 0.720 & $\begin{array}{c}13 \\
(2.89 \%)\end{array}$ & $\begin{array}{c}24 \\
(15.00 \%)\end{array}$ & $<0.002^{*}$ \\
\hline $\begin{array}{l}\text { Kidney } \\
\text { failure, GFR } \\
<15 \mathrm{~mL} / \mathrm{min} \\
(\%)\end{array}$ & $\begin{array}{c}208 \\
(3.53 \%)\end{array}$ & $22(3.61 \%)$ & 1 & $\begin{array}{c}10 \\
(2.22 \%)\end{array}$ & $\begin{array}{c}12 \\
(7.50 \%)\end{array}$ & $0.005^{\star}$ \\
\hline $\begin{array}{l}\text { Liver function } \\
\text { Elevated liver } \\
\text { enzymes (\%) }\end{array}$ & $\begin{array}{c}837 \\
(16.89 \%)\end{array}$ & $\begin{array}{c}74 \\
(13.99 \%)\end{array}$ & 0.101 & $\begin{array}{c}30 \\
(9.62 \%)\end{array}$ & $\begin{array}{c}26 \\
(26.26 \%)\end{array}$ & $<0.002^{*}$ \\
\hline $\begin{array}{l}\text { Diabetes } \\
\text { management }\end{array}$ & & & & & & \\
\hline Untreated (\%) & $\begin{array}{c}336 \\
(29.8 \%)\end{array}$ & $38(24.5 \%)$ & $0.210^{*}$ & $\begin{array}{c}27 \\
(24.3 \%)\end{array}$ & $\begin{array}{c}11 \\
(25.0 \%)\end{array}$ & $1^{*}$ \\
\hline $\begin{array}{l}\text { Insulin and } \\
\text { OADs (\%) }\end{array}$ & $\begin{array}{c}258 \\
(22.9 \%)\end{array}$ & $43(27.7 \%)$ & $0.213^{*}$ & $\begin{array}{c}30 \\
(27.0 \%)\end{array}$ & $\begin{array}{c}13 \\
(29.6 \%)\end{array}$ & $0.907^{\star}$ \\
\hline $\begin{array}{l}\text { Insulin only } \\
\text { (\%) }\end{array}$ & $\begin{array}{c}231 \\
(20.5 \%)\end{array}$ & $23(14.8 \%)$ & $0.124^{*}$ & $10(9.0 \%)$ & $\begin{array}{c}13 \\
(29.6 \%)\end{array}$ & $0.003^{*}$ \\
\hline OAD only (\%) & $\begin{array}{c}304 \\
(26.9 \%)\end{array}$ & $51(32.9 \%)$ & $0.143^{*}$ & $\begin{array}{c}44 \\
(39.6 \%)\end{array}$ & $7(15.9 \%)$ & $0.008^{*}$ \\
\hline $\begin{array}{l}\text { Incl. } \\
\text { metformin } \\
(\%)\end{array}$ & - & - & - & $\begin{array}{c}21 \\
(18.9 \%)\end{array}$ & $2(4.6 \%)$ & $0.024^{* *}$ \\
\hline $\begin{array}{l}\text { Excl. } \\
\text { metformin } \\
\text { (\%) }\end{array}$ & - & - & - & $\begin{array}{c}23 \\
(20.7 \%)\end{array}$ & $\begin{array}{c}5 \\
(11.46 \%)\end{array}$ & $0.247^{* *}$ \\
\hline
\end{tabular}

Bold numbers indicate significant differences $(p<0.05)$ between compared groups. aHT: arterial hypertension, BMI: body mass index, COPD: chronic obstructive pulmonary disease, GFR: glomerular filtration rate, IQR: interquartile range, OAD: oral anti-diabetics, \$ Wilcoxon rank sum test, * Chi Square test **Fisher test

251 Patients suffering from chronic heart failure or COPD were less likely to be

252 tested positive for SARS-CoV-2, but more likely to develop a severe COVID-19

253 course. In contract, significantly more asthmatic patients were tested positive

254 for SARS-CoV-2 than negative. However, with regards to clinical manifestation,

255 no difference could be observed between the two groups. Cancer patients were

256 less likely to be tested positive for SARS-CoV-2, but no significant difference in

257 severity was observed. 
medRxiv preprint doi: https://doi.org/10.1101/2021.03.25.21254314; this version posted March 26, 2021. The copyright holder for this preprint (which was not certified by peer review) is the author/funder, who has granted medRxiv a license to display the preprint in perpetuity.

It is made available under a CC-BY-NC-ND 4.0 International license .

NLP COVID-19, Schöning (2021)

258 Diabetes treatment was not associated with the risk for tested positive for

259 SARS-CoV-2, but with its clinical consequences. Treatment with OAD only was

260 significantly associated with less cases of a severe outcome, whereas

261 treatment with insulin only showed the opposite effect. A subgroup analysis of

262 the OAD only group showed that this effect might be linked to metformin. No

263 differences were seen for untreated and insulin/OAD co-medicated patients.

264 Normal kidney function around the time of SARS-CoV-2 testing was associated

265 with benign courses, whereas a severely impaired kidney function of kidney

266 failure was more often seen in severe cases. Additionally, elevated liver

267 enzymes were also seen more often in cases with severe COVID-19.

\section{DISCUSSION}

269 During the ongoing pandemic, the swift identification of patients at risk for

270 infection and severe courses of COVID-19 is highly important. Manual

271 identification of risk factors is a time-consuming task, especially for patients with

272 co-morbidities, as the respective medical histories might be very long. Using

273 NLP on EHRs poses several challenges, as written clinical text contains

274 abbreviations, acronyms, spelling errors, and nested negations.(28)

275 Furthermore, most available software solutions focus on English language text.

276 We were able to develop a suitable NLP algorithm to automatically detect

277 relevant risk factors for COVID-19 in the medical history of patients at time of

278 admission. The selected key terms allowed for a detection in German EHRs

279 with an error rate of $\leq 2 \%$ on the validation dataset and thus can be used for

280 automated real-time detection to support risk assessment and triage at point-

281 of-care. 
medRxiv preprint doi: https://doi.org/10.1101/2021.03.25.21254314; this version posted March 26, 2021. The copyright holder for this preprint (which was not certified by peer review) is the author/funder, who has granted medRxiv a license to display the preprint in perpetuity.

It is made available under a CC-BY-NC-ND 4.0 International license .

NLP COVID-19, Schöning (2021)

282 Old age, male sex, higher BMI, arterial hypertension, and diabetes were

283 identified as risk factors for a positive COVID-19 test result as well as for a more

284 severe clinical outcome. This is in line with observations of other studies and

285 reviews.(29) Old age is generally accepted as a risk factor for severe clinical

286 manifestations, probably due to coexisting age-dependent risk factors (e.g.

287 diabetes, arterial hypertension, coronary heart disease, malnutrition) and

288 remodelling of the immune system (immunosenecence).(3, 4, 30) Sex-specific

289 differences in immune response during COVID-19 might be responsible for the

290 higher vulnerability of males, $(5,31)$ but also life style (e.g. personal hygiene

291 and smoking)(32) might contribute to this observation. Obesity is not only

292 associated with other comorbidities such as diabetes and arterial hypertension,

293 but also several physiological changes, e.g. chronic inflammation, endocrinal

294 dysfunction, impaired pulmonary perfusion, and immune dysregulation, which

295 may contribute to severe clinical manifestations.(7-10) Furthermore, several

296 comorbidities can often also coexist and a number of two or more comorbidities

297 were a significant factor for a more severe COVID-19 clinical outcome in

298 previous studies.(33)

299 Diabetes was seen in approximately one third of patients with a severe disease

300 course. This proportion was within the range of other studies. $(34,35)$

301 Monotherapy of diabetes before admission in COVID-19 patients with insulin

302 was associated with a higher percentage of severe outcomes (29.6\% vs. $9.0 \%)$.

303 By contrast, OAD treatment that included metformin was associated with a

304 higher percentage of non-severe disease progression (18.9\% vs. $4.6 \%)$. This

305 decrease in severity was significant for the metformin group $(p<0.02)$. OAD

306 treatment that did not include metformin was not significantly associated with 
medRxiv preprint doi: https://doi.org/10.1101/2021.03.25.21254314; this version posted March 26, 2021. The copyright holder for this preprint (which was not certified by peer review) is the author/funder, who has granted medRxiv a license to display the preprint in perpetuity. It is made available under a CC-BY-NC-ND 4.0 International license .

NLP COVID-19, Schöning (2021)

307 disease severity. This is in line with recent clinical reports that metformin

308 treatment of diabetic COVID-19 patients resulted in a reduced mortality 309 rate.(36-38) Metformin acts by activating the AMP-activated protein kinase 310 AMPK,(39) which then phosphorylates angiotensin-converting enzyme 2 311 (ACE2) causing increase in ACE2 expression.(40) Even though ACE2 serves 312 as molecular target for SARS-CoV-2, it also exhibits protective effects.(41-45)

313 Furthermore, AMPK also inhibits the protein kinase B (AKT)/mammalian target 314 of rapamycin (mTOR) pathway that is essential for viral translation.(46) Finally, 315 metformin, inhibits inflammatory pathways and elevated inflammatory immune responses (cytokine storms).(47)

317 Possible reasons for the observation that COPD was associated with lower

318 proportion of a positive test for COVID-19, which is also seen in other published 319 data,(48) include a potential effect of smoking, the most predominant risk factor 320 for the development of COPD. Smokers have been reported to be less 321 susceptible to COVID-19.(49,50) Furthermore, given the common symptoms 322 of COPD such as cough, increased phlegm, shortness of breath, and 323 decreased oxygen levels, it is also possible that due to the similarity in clinical 324 presentation with a SARS-CoV-2 infection might lead to a higher test rate in 325 COPD patients and thus more negative SARS-CoV-2 test results, while 326 respiratory diseases including COPD might be under-diagnosed in some 327 positively tested cases.(33) A possible protective role of regular treatment with 328 inhaled corticosteroids in patients with COPD or asthma was not confirmed by 329 Schultze et al.(51) Despite the often similar symptoms, and the presence of 330 chronic airway inflammation in both COPD and asthma, the generally better 331 outcomes in cases with asthma might be due to the usually younger age of 
medRxiv preprint doi: https://doi.org/10.1101/2021.03.25.21254314; this version posted March 26, 2021. The copyright holder for this preprint (which was not certified by peer review) is the author/funder, who has granted medRxiv a license to display the preprint in perpetuity.

It is made available under a CC-BY-NC-ND 4.0 International license .

NLP COVID-19, Schöning (2021)

332 these patients or to the non-reversible structural changes of the airways in case

333 of COPD.

334 Our study has several limitations. As the IHG is a major hospital centre in the 335 region, patients admitted to the hospital for other reasons were also tested for 336 SARS-CoV-2 if they displayed any symptoms indicative for COVID-19. The 337 patients in the SARS-CoV-2 negative cohort probably have more health-related 338 problems than the general population. This effect is further corroborated as we 339 only analysed patients with available EHRs, and, due to the retrospective 340 nature of the study, had no information on patients tested at the ambulant 341 COVID-19 test centre without being admitted to the IHG as in- or out-patients.

342 This was partially mitigated by including records from the three months 343 preceding diagnosis. Therefore the higher incidence of specific comorbidities in 344 the SARS-CoV-2 negative cohort might represent a selection bias. Additionally, 345 we did not perform a case-controlled study or adjusted for cofounding factors 346 such as smoking or age. Furthermore, with the exception of diabetes and renal 347 function, we did no differentiate between the different stages and severities of 348 the diseases. This issue can be addressed by refining the key terms list in a 349 subsequent study.

350 The validated error rate for the NLP detection of the different disease is around $3512 \%$. Due to this low error rate, the pronounced contrast between significant 352 features, and the large amount of EHRs analysed, it is not expected to affect 353 statistical conclusions. The main focus of the analysis were patients tested 354 positive for SARS-CoV-2, and approximately $25 \%$ of these patients were used 355 for the validation of NLP and thus manually screened for the diseases of 356 interest. 
medRxiv preprint doi: https://doi.org/10.1101/2021.03.25.21254314; this version posted March 26, 2021. The copyright holder for this preprint (which was not certified by peer review) is the author/funder, who has granted medRxiv a license to display the preprint in perpetuity. It is made available under a CC-BY-NC-ND 4.0 International license .

NLP COVID-19, Schöning (2021)

\section{$357 \quad 5$ CONCLUSION}

358 In conclusion, we were able to develop a suitable NLP algorithm to 359 automatically detect risk factors for COVID-19 in German EHRs at time of 360 admission with an error rate of $\leq 2 \%$. Our technique should be relative easily

361 transferable to other languages by amending the key terms list and the negation

362 detection accordingly. Use of NLP and data mining can provide a timesaving 363 support for risk assessment and triage at point-of-care, especially in patients 364 with long medical histories and multiple comorbidities. In the future, the same 365 technique could also be used for vaccine prioritization for the automated and 366 time efficient identification of persons at risk.

\section{$367 \quad 6$ DECLARATIONS}

\subsection{Authors' contributions}

$369 \mathrm{FH}$ and VS conceptualized this study. VS and FH performed the data analysis.

$370 \mathrm{FH}$ and EL contributed to data extraction. All authors critically revised and 371 approved the final manuscript.

\subsection{Acknowledgements}

373 We thank Noel Frey, Myoori Wijayasingham, and the Insel Data Science Center

374 for database and infrastructure support.

\section{$375 \quad 6.3$ Competing interest}

376 None. 
medRxiv preprint doi: https://doi.org/10.1101/2021.03.25.21254314; this version posted March 26, 2021. The copyright holder for this preprint (which was not certified by peer review) is the author/funder, who has granted medRxiv a license to display the preprint in perpetuity.

It is made available under a CC-BY-NC-ND 4.0 International license .

NLP COVID-19, Schöning (2021)

377

378

379

380

381

382

383

384

385

386

387

388

\subsection{Funding}

None.

\subsection{Ethics approval and consent to participate}

The study was approved by the Cantonal Ethics Committee of Bern (Project-ID 2020-00973). Participants either agreed to a general research consent or, for participants with no registered general research consent status (neither agreement nor rejection), a waiver of consent was granted by the ethics committee.

\subsection{Availability of data and materials}

The datasets used and/or analyses during the current study are available from the corresponding author on reasonable request.

\section{REFERENCES}

$1 \mathrm{Wu} F$, Zhao $\mathrm{S}$, Yu B, et al. A new coronavirus associated with human respiratory disease in China. Nature. 2020 2020/03/01;579(7798):265-9.

2 Johns Hopkins University. COVID-19 Dashboard by the Center for Systems Science and Engineering (CSSE) at Johns Hopkins University (JHU). 2020 [cited 2020 17.11.2020]; Available from: https://coronavirus.jhu.edu/map.html 3 Bencivenga L, Rengo G, Varricchi G. Elderly at time of COronaVIrus disease 2019 (COVID-19): possible role of immunosenescence and malnutrition. GeroScience. 2020 2020/08/01;42(4):1089-92.

4 Cunha LL, Perazzio SF, Azzi J, Cravedi P, Riella LV. Remodeling of the Immune Response With Aging: Immunosenescence and Its Potential Impact on COVID-19 Immune Response. Frontiers in immunology. 2020;11:1748-. 5 Peckham H, de Gruijter NM, Raine C, et al. Male sex identified by global COVID-19 meta-analysis as a risk factor for death and ITU admission. Nature communications. 2020 2020/12/09;11(1):6317.

6 Klein SL, Dhakal S, Ursin RL, Deshpande S, Sandberg K, Mauvais-Jarvis F. Biological sex impacts COVID-19 outcomes. PLOS Pathogens. 2020;16(6):e1008570.

7 Kang Z, Luo S, Gui Y, et al. Obesity is a potential risk factor contributing to clinical manifestations of COVID-19. International journal of obesity. 2020 Dec;44(12):2479-85. 
medRxiv preprint doi: https://doi.org/10.1101/2021.03.25.21254314; this version posted March 26, 2021. The copyright holder for this preprint (which was not certified by peer review) is the author/funder, who has granted medRxiv a license to display the preprint in perpetuity. It is made available under a CC-BY-NC-ND 4.0 International license .

NLP COVID-19, Schöning (2021)

4098 Kwok S, Adam S, Ho JH, et al. Obesity: A critical risk factor in the COVID-19 410 pandemic. Clinical obesity. 2020 Dec;10(6):e12403.

4119 Foldi M, Farkas N, Kiss S, et al. Obesity is a risk factor for developing critical condition in COVID-19 patients: A systematic review and meta-analysis. Obesity reviews : an official journal of the International Association for the Study of Obesity. 2020 Oct;21(10):e13095.

10 Sattar N, Mclnnes IB, McMurray JJV. Obesity Is a Risk Factor for Severe COVID-19 Infection: Multiple Potential Mechanisms. Circulation. 2020 Jul 7;142(1):4-6.

11 Zhu L, She Z-G, Cheng X, et al. Association of Blood Glucose Control and Outcomes in Patients with COVID-19 and Pre-existing Type 2 Diabetes. Cell metabolism. 2020 2020/06/02/;31(6):1068-77.e3.

12 Tadic $M$, Cuspidi $C$. The influence of diabetes and hypertension on outcome in COVID-19 patients: Do we mix apples and oranges? The Journal of Clinical Hypertension. 2020 2020/12/25;n/a(n/a).

13 Lim S, Bae JH, Kwon H-S, Nauck MA. COVID-19 and diabetes mellitus: from pathophysiology to clinical management. Nature Reviews Endocrinology. 2021 2021/01/01;17(1):11-30.

14 Mehra MR, Desai SS, Kuy S, Henry TD, Patel AN. Cardiovascular Disease, Drug Therapy, and Mortality in Covid-19. N Engl J Med. 2020 Jun 18;382(25):e102.

15 Ssentongo $P$, Ssentongo AE, Heilbrunn ES, Ba DM, Chinchilli VM. Association of cardiovascular disease and 10 other pre-existing comorbidities with COVID-19 mortality: A systematic review and meta-analysis. PLOS ONE. 2020;15(8):e0238215.

16 Inciardi RM, Adamo M, Lupi L, et al. Characteristics and outcomes of patients hospitalized for COVID-19 and cardiac disease in Northern Italy. European Heart Journal. 2020;41(19):1821-9.

17 Yang J, Zheng Y, Gou X, et al. Prevalence of comorbidities and its effects in patients infected with SARS-CoV-2: a systematic review and meta-analysis. International Journal of Infectious Diseases. 2020 2020/05/01/;94:91-5. 18 Olloquequi J. COVID-19 Susceptibility in chronic obstructive pulmonary disease. European Journal of Clinical Investigation. 2020 2020/10/01;50(10):e13382.

19 Desai A, Khaki AR, Kuderer NM. Use of Real-World Electronic Health Records to Estimate Risk, Risk Factors, and Disparities for COVID-19 in Patients With Cancer. JAMA Oncology. 2021;7(2):227-9.

20 Wang Q, Davis PB, Gurney ME, Xu R. COVID-19 and dementia: Analyses of risk, disparity, and outcomes from electronic health records in the US. Alzheimer's \& Dementia. 2021 2021/02/09;n/a(n/a).

21 Nandy K, Salunke A, Pathak SK, et al. Coronavirus disease (COVID-19): A systematic review and meta-analysis to evaluate the impact of various comorbidities on serious events. Diabetes \& Metabolic Syndrome: Clinical Research \& Reviews. 2020 2020/09/01/;14(5):1017-25.

22 Liu N, Sun J, Wang X, Zhao M, Huang Q, Li H. The Impact of Dementia on the Clinical Outcome of COVID-19: A Systematic Review and Meta-Analysis. Journal of Alzheimer's Disease. 2020;78:1775-82.

23 Schöning V, Liakoni E, Baumgartner C, et al. Development and validation of a prognostic COVID-19 severity assessment (COSA) score and machine 
medRxiv preprint doi: https://doi.org/10.1101/2021.03.25.21254314; this version posted March 26, 2021. The copyright holder for this preprint (which was not certified by peer review) is the author/funder, who has granted medRxiv a license to display the preprint in perpetuity. It is made available under a CC-BY-NC-ND 4.0 International license .

NLP COVID-19, Schöning (2021)

458 learning models for patient triage at a tertiary hospital. Journal of Translational 459 Medicine. 2021 2021/02/05;19(1):56.

46024 National Kidney Foundation. K/DOQI clinical practice guidelines for chronic 461 kidney disease: evaluation, classification, and stratification. Am J Kidney Dis 462 2002;39(2 Suppl 1):S1-266.

46325 Cotik V, Roller R, Xu F, Uszkoreit H, Budde K, Schmidt D. Negation 464 Detection in Clinical Reports Written in German; 2016.

46526 Bird S, Klein E, Loper E. Natural Language Processing with Python: O'Reilly 466 Media, Inc.; 2009.

46727 Chapman WW, Bridewell W, Hanbury P, Cooper GF, Buchanan BG. A 468 Simple Algorithm for Identifying Negated Findings and Diseases in Discharge 469 Summaries. Journal of Biomedical Informatics. 2001 2001/10/01/;34(5):301-10. 47028 Dalianis H. Clinical Text Mining: Secondary Use of Electronic Patient 471 Records: Springer Nature; 2018.

47229 Wolff D, Nee S, Hickey NS, Marschollek M. Risk factors for Covid-19 severity 473 and fatality: a structured literature review. Infection. 2020 2020/08/28.

47430 Romero Starke K, Petereit-Haack G, Schubert M, et al. The Age-Related 475 Risk of Severe Outcomes Due to COVID-19 Infection: A Rapid Review, Meta476 Analysis, and Meta-Regression. International Journal of Environmental 477 Research and Public Health. 2020;17(16):5974.

47831 Takahashi T, Ellingson MK, Wong $P$, et al. Sex differences in immune 479 responses that underlie COVID-19 disease outcomes. Nature. 2020 480 2020/12/01;588(7837):315-20.

48132 Anca PS, Toth PP, Kempler P, Rizzo M. Gender differences in the battle 482 against COVID-19: Impact of genetics, comorbidities, inflammation and lifestyle 483 on differences in outcomes. International Journal of Clinical Practice. 2021 484 2021/02/01;75(2):e13666.

48533 Guan W-j, Liang W-h, Zhao Y, et al. Comorbidity and its impact on 1590 486 patients with Covid-19 in China: A Nationwide Analysis. European Respiratory 487 Journal. 2020:2000547.

48834 Bhatraju PK, Ghassemieh BJ, Nichols M, et al. Covid-19 in Critically III 489 Patients in the Seattle Region - Case Series. N Engl J Med. 2020 May $490 \quad 21 ; 382(21): 2012-22$.

49135 Arentz M, Yim E, Klaff L, et al. Characteristics and Outcomes of 21 Critically 492 III Patients With COVID-19 in Washington State. Jama. 2020;323(16):1612-4.

49336 Nafakhi H, Alareedh M, Al-Buthabhak K, Shaghee F, Nafakhi A, Kasim S. 494 Predictors of adverse in-hospital outcome and recovery in patients with 495 diabetes mellitus and COVID-19 pneumonia in Iraq. Diabetes Metab Syndr. 4962020 Dec 5;15(1):33-8.

49737 Lally MA, Tsoukas P, Halladay CW, O'Neill E, Gravenstein S, Rudolph JL. 498 Metformin is Associated with Decreased 30-Day Mortality Among Nursing 499 Home Residents Infected with SARS-CoV2. J Am Med Dir Assoc. 2021 500 Jan;22(1):193-8.

50138 Kow CS, Hasan SS. Mortality risk with preadmission metformin use in 502 patients with COVID-19 and diabetes: A meta-analysis. J Med Virol. 2021 503 Feb;93(2):695-7.

50439 Kahn BB, Alquier T, Carling D, Hardie DG. AMP-activated protein kinase: 505 ancient energy gauge provides clues to modern understanding of metabolism. 506 Cell Metab. 2005 Jan;1(1):15-25. 
medRxiv preprint doi: https://doi.org/10.1101/2021.03.25.21254314; this version posted March 26, 2021. The copyright holder for this preprint (which was not certified by peer review) is the author/funder, who has granted medRxiv a license to display the preprint in perpetuity. It is made available under a CC-BY-NC-ND 4.0 International license .

NLP COVID-19, Schöning (2021)

50740 Saheb Sharif-Askari N, Saheb Sharif-Askari F, Mdkhana B, et al. Effect of 508 common medications on the expression of SARS-CoV-2 entry receptors in liver 509 tissue. Arch Toxicol. 2020 Dec;94(12):4037-41.

51041 Behl T, Kaur I, Bungau S, et al. The dual impact of ACE2 in COVID-19 and 511 ironical actions in geriatrics and pediatrics with possible therapeutic solutions. 512 Life Sci. 2020;257:118075-.

51342 Li Y, Zhou W, Yang L, You R. Physiological and pathological regulation of 514 ACE2, the SARS-CoV-2 receptor. Pharmacol Res. 2020;157:104833-.

51543 Kuba K, Imai Y, Ohto-Nakanishi T, Penninger JM. Trilogy of ACE2: a 516 peptidase in the renin-angiotensin system, a SARS receptor, and a partner for amino acid transporters. Pharmacol Ther. 2010;128(1):119-28.

44 Imai $Y$, Kuba K, Rao S, et al. Angiotensin-converting enzyme 2 protects from severe acute lung failure. Nature. 2005 2005/07/01;436(7047):112-6. $45 \mathrm{Ni} \mathrm{W}$, Yang $X$, Yang $D$, et al. Role of angiotensin-converting enzyme 2 (ACE2) in COVID-19. Critical Care. 2020 2020/07/13;24(1):422. 46 Karam BS, Morris RS, Bramante CT, et al. mTOR inhibition in COVID-19: A commentary and review of efficacy in RNA viruses. J Med Virol. 2021 Apr;93(4):1843-6.

52547 Chen X, Guo H, Qiu L, Zhang C, Deng Q, Leng Q. Immunomodulatory and Antiviral Activity of Metformin and Its Potential Implications in Treating Coronavirus Disease 2019 and Lung Injury. Front Immunol. 2020;11:2056. 48 Deslée G, Zysman M, Burgel PR, et al. Chronic obstructive pulmonary disease and the COVID-19 pandemic: Reciprocal challenges. Respir Med Res. 2020;78:100764-.

49 Tajlil A, Ghaffari S, Pourafkari L, Mashayekhi S, Roshanravan N. Nicotine and smoking in the COVID-19 era. J Cardiovasc Thorac Res. 2020;12(2):1369.

53450 Farsalinos K, Barbouni A, Niaura R. Systematic review of the prevalence of current smoking among hospitalized COVID-19 patients in China: could nicotine be a therapeutic option? Internal and emergency medicine. 2020 Aug;15(5):845-52.

53851 Schultze A, Walker AJ, MacKenna B, et al. Risk of COVID-19-related death among patients with chronic obstructive pulmonary disease or asthma OpenSAFELY platform. The Lancet Respiratory Medicine. 2020;8(11):1106-20. 
medRxiv preprint doi: https://doi.org/10.1101/2021.03.25.21254314; this version posted March 26, 2021. The copyright holder for this preprint (which was not certified by peer review) is the author/funder, who has granted medRxiv a license to display the preprint in perpetuity. It is made available under a CC-BY-NC-ND 4.0 International license .

NLP COVID-19, Schöning (2021)

\section{FIGURES}

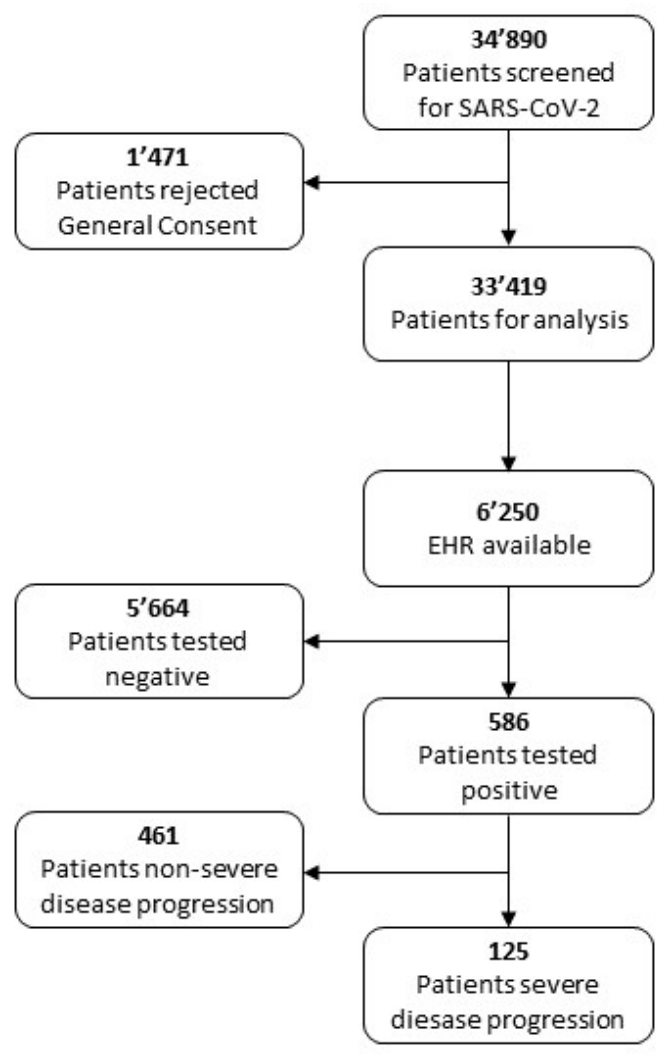

544 Figure 1: Flowchart of the selection of the patient population included in the

545 study

546

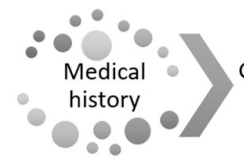

547 Figure 2: Data preparation steps for the detection of diseases in a free-text 
medRxiv preprint doi: https://doi.org/10.1101/2021.03.25.21254314; this version posted March 26, 2021. The copyright holder for this preprint (which was not certified by peer review) is the author/funder, who has granted medRxiv a license to display the preprint in perpetuity.

It is made available under a CC-BY-NC-ND 4.0 International license .

NLP COVID-19, Schöning (2021)

5509 SUPPLEMENTARY MATERIAL

551 Table S1: Overview on error rate of Natural Language Processing (NLP)

552 detection of disease status on the validation dataset and the final key terms

553 used for NLP.

\begin{tabular}{|c|c|c|}
\hline Disease & $\begin{array}{l}\begin{array}{l}\text { Error rate } \\
\text { validation } \\
\text { dataset } \\
\text { cases })\end{array} \quad(138 \\
\end{array}$ & Key terms \\
\hline Diabetes & $0.7 \%(1 / 138)$ & $\begin{array}{l}\text { diabetes, diabetisch, praediabetisch, } \\
\text { praediabetes, } \\
\text { zuckerkrankheit, gestationsdiabetes }\end{array}$ \\
\hline aHT & $0.7 \%(1 / 138)$ & $\begin{array}{l}\text { aht, } \\
\text { hypertensive kardiopathie, hypertensive } \\
\text { herzkrankheit, arterielle hypertonus, arterielle } \\
\text { hypertension, hypertensive entgleisung, } \\
\text { bluthochdruck, hypertensive notfall }\end{array}$ \\
\hline Asthma & $1.4 \%(2 / 138)$ & $\begin{array}{l}\text { asthma, asthma bronchiale, bronchialasthma, } \\
\text { belastungsasthma, belastungsasthma } \\
\text { bronchiale }\end{array}$ \\
\hline COPD & $0.7 \%(1 / 138)$ & $\begin{array}{l}\text { chronisch obstruktive pneumopathie, } \\
\text { chronisch obstruktive atemwegserkrankung, } \\
\text { chronisch obstruktive lungenerkrankung, copd, } \\
\text { chronisch obstruktive bronchitis, chronisch } \\
\text { bronchitis emphysem, chronisch obstruktive } \\
\begin{array}{l}\text { lungenkrankheit, } \\
\text { obstruktive } \\
\text { lungentilationsstoerung, chronisch bronchitis }\end{array}\end{array}$ \\
\hline $\begin{array}{l}\text { Chronic } \quad \text { heart } \\
\text { failure }\end{array}$ & $0.7 \%(1 / 138)$ & $\begin{array}{l}\text { herzinsuffizienz, } \\
\text { kardiopathie, nyha, Ifef, linksherzinsuffizienz, } \\
\text { rechtsherzinsuffizienz, } \\
\text { herzkrankheit, hfref, hfmref, hfpef }\end{array}$ \\
\hline Atrial fibrillation & $0.7 \%(1 / 138)$ & $\begin{array}{l}\text { vorhofflimmern, vhf, vorhofflattern, afib, vfli, } \\
\text { vofli, vhfli, vfla, vhfla, vofla, ehra }\end{array}$ \\
\hline $\begin{array}{l}\text { Coronary heart } \\
\text { disease }\end{array}$ & $1.4 \%(2 / 138)$ & 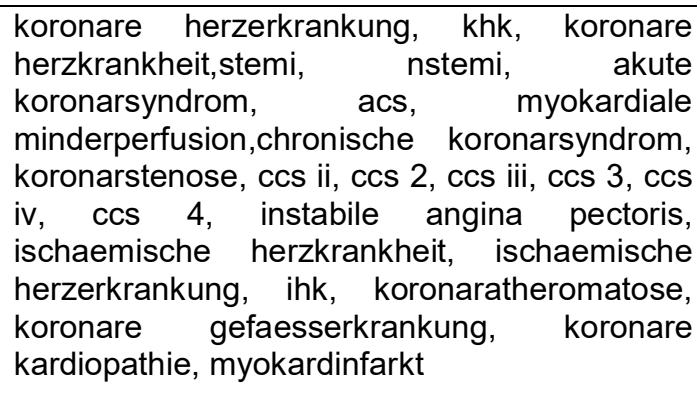 \\
\hline Dementia & $1.4 \%(2 / 138)$ & $\begin{array}{l}\text { demenz, dementielle, demenzielle, mild } \\
\text { cognitive impairment, kognitive stoerung, mci, } \\
\begin{array}{l}\text { alzheimer, } \\
\text { beeintraechtigung, lewy }\end{array}\end{array}$ \\
\hline
\end{tabular}


medRxiv preprint doi: https://doi.org/10.1101/2021.03.25.21254314; this version posted March 26, 2021. The copyright holder for this preprint (which was not certified by peer review) is the author/funder, who has granted medRxiv a license to display the preprint in perpetuity.

It is made available under a CC-BY-NC-ND 4.0 International license .

NLP COVID-19, Schöning (2021)

\begin{tabular}{|c|c|c|}
\hline Disease & $\begin{array}{l}\begin{array}{l}\text { Error rate } \\
\text { validation } \\
\text { dataset } \\
\text { cases })\end{array} \\
\end{array}$ & Key terms \\
\hline Cancer & $2.1 \%(3 / 138)$ & $\begin{array}{l}\text { Key terms according to Supplementary Material } \\
\text { Table S2 }\end{array}$ \\
\hline Insulin & - & $\begin{array}{lc}\text { insulin, insulinpflichtig, } & \text { insulinabhaengig, } \\
\text { basisinsulintherapie, } & \text { insulintherapie, } \\
\text { insulinpumpe, } & \text { insulinperfusor, } \\
\text { insulinbasistherapie, levemir, novorapid, lantus, } \\
\text { tresiba, toujeo, iddm] }\end{array}$ \\
\hline OAD & - & $\begin{array}{l}\text { oad, metformin, orale anti diabetikum, orale } \\
\text { antidiabetikum, biguanid, glitazone, } \\
\text { sulfonylharnstoffe, glinide, inkretine, alpha } \\
\text { glucosidasehemmer, dpp } 4 \text { inhibitor, sglt } 2 \\
\text { inhibitor, orale anti diabetika, orale } \\
\text { antidiabetika, sitagliptin, janumet, kombiglyze }\end{array}$ \\
\hline
\end{tabular}

554

555 Table S2: Key terms for the detection of cancer

\begin{tabular}{|l|}
\hline Key terms \\
\hline adenokarzinom \\
\hline adenokarzinomatoes \\
\hline adenokarzinominfiltrate \\
\hline adenokarzinomzellen \\
\hline adenomkarzinom \\
\hline adenomkarzinominfiltrate \\
\hline aderhautmelanom \\
\hline adnexkarzinom \\
\hline aktinische keratose \\
\hline akustikusneurinom \\
\hline all \\
\hline alveolarzellkarzinom \\
\hline aml \\
\hline analkarzinom \\
\hline analkrebs \\
\hline angiosarkom \\
\hline antrumkarzinom \\
\hline astrozytom \\
\hline augentumor \\
\hline basaliom \\
\hline basalkarzinom \\
\hline
\end{tabular}


medRxiv preprint doi: https://doi.org/10.1101/2021.03.25.21254314; this version posted March 26, 2021. The copyright holder for this preprint (which was not certified by peer review) is the author/funder, who has granted medRxiv a license to display the preprint in perpetuity.

\section{It is made available under a CC-BY-NC-ND 4.0 International license .}

\section{NLP COVID-19, Schöning (2021)}

\begin{tabular}{|c|}
\hline Key terms \\
\hline basalzellkarzinom \\
\hline bauchspeicheldruesenkrebs \\
\hline bauchspeichelkrebs \\
\hline blasenkarzinom \\
\hline blasenkarzinom, harnblasenkarzinom \\
\hline bronchialkarzinom \\
\hline bronchuskarzinom \\
\hline brustkrebs \\
\hline burkitt lymphom \\
\hline cervixkarzinom \\
\hline cholangiokarzinom \\
\hline chondrosarkom \\
\hline chondrosarkom \\
\hline chondrosarkomanteilen \\
\hline ciliarkoerpermelanom \\
\hline cll \\
\hline $\mathrm{cml}$ \\
\hline coecumkarzinom \\
\hline colonkarzinom \\
\hline corpuskarzinom \\
\hline darmkrebs \\
\hline denokarzinom \\
\hline dermatofibrosarkoms \\
\hline dickdarmkarzinom \\
\hline dickdarmkarzinom \\
\hline dickdarmkrebs \\
\hline doppelkarzinom \\
\hline dünndarmkarzinom \\
\hline duodenalkarzinom \\
\hline eierstockkrebs \\
\hline endometrioidesadenokarzinom \\
\hline endometriumkarzinom \\
\hline endometriumkarzinomrezidiv \\
\hline endometriumskarzinomrezidiv \\
\hline ependymome \\
\hline ewing sarkom \\
\hline ewingsarkom \\
\hline
\end{tabular}


medRxiv preprint doi: https://doi.org/10.1101/2021.03.25.21254314; this version posted March 26, 2021. The copyright holder for this preprint (which was not certified by peer review) is the author/funder, who has granted medRxiv a license to display the preprint in perpetuity.

\section{It is made available under a CC-BY-NC-ND 4.0 International license .}

\section{NLP COVID-19, Schöning (2021)}

\begin{tabular}{|c|}
\hline Key terms \\
\hline fibrosarkom \\
\hline gallenblasenkarzinom \\
\hline gallengangkarzinom \\
\hline gastrointestinale stromakarzinom \\
\hline gebaermutterhalskrebs \\
\hline gebaermutterhalskrebs \\
\hline gebaermutterkoerperkarzinom \\
\hline gebaermutterkrebs \\
\hline gehirntumor \\
\hline genkarzinom \\
\hline gist \\
\hline glioblastom \\
\hline gliome \\
\hline haarzelleukaemie \\
\hline haemangiosarkom \\
\hline harnblasenkarzinom \\
\hline harnroehrenkarzinom \\
\hline hautkarzinomen \\
\hline hautkrebs \\
\hline hautkrebsnekrosen \\
\hline hautkrebssetomelanomm \\
\hline hemangiosarkom \\
\hline hirntumor \\
\hline hodenkarzinom \\
\hline hodgkin \\
\hline hypopharynxkarzinom \\
\hline hypopharynxkarzinoms \\
\hline hypophysentumor \\
\hline kardiakarzinom \\
\hline karzinoid \\
\hline karzinom \\
\hline karzinoma \\
\hline karzinomablegers \\
\hline karzinomanteile \\
\hline karzinomatoese \\
\hline karzinomatosa \\
\hline karzinomatose \\
\hline
\end{tabular}


medRxiv preprint doi: https://doi.org/10.1101/2021.03.25.21254314; this version posted March 26, 2021. The copyright holder for this preprint (which was not certified by peer review) is the author/funder, who has granted medRxiv a license to display the preprint in perpetuity.

\section{It is made available under a CC-BY-NC-ND 4.0 International license .}

\section{NLP COVID-19, Schöning (2021)}

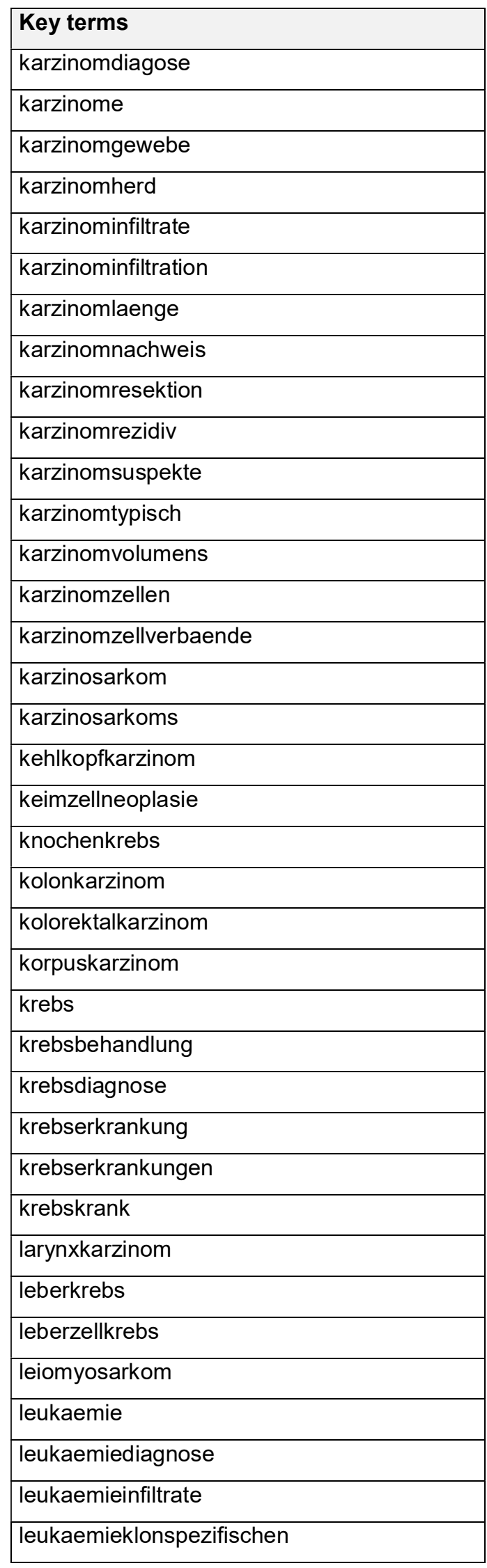


medRxiv preprint doi: https://doi.org/10.1101/2021.03.25.21254314; this version posted March 26, 2021. The copyright holder for this preprint (which was not certified by peer review) is the author/funder, who has granted medRxiv a license to display the preprint in perpetuity.

\section{It is made available under a CC-BY-NC-ND 4.0 International license .}

\section{NLP COVID-19, Schöning (2021)}

\begin{tabular}{|c|}
\hline Key terms \\
\hline leukaemiepersistenz \\
\hline leukaemierezidiv \\
\hline leukaemiezellen \\
\hline leyomyosarkom \\
\hline lidtumor \\
\hline liposarkom \\
\hline liposarkomanteile \\
\hline lippentumor \\
\hline lungenadenokarzinom \\
\hline lungenkarzinom \\
\hline lungenkrebs \\
\hline lymphangiokarzinomatose \\
\hline lymphdruesenkrebs \\
\hline lymphgranulomatose \\
\hline lymphomlymphknotenmetastasenprogression \\
\hline magenkarzinom \\
\hline magenkrebs \\
\hline malignes myelom \\
\hline mammakarzinom \\
\hline mastdarmkarzinom \\
\hline medulloblastome \\
\hline melanom \\
\hline melanoma \\
\hline melanomentfernung \\
\hline melanomexzision \\
\hline melanomnachweis \\
\hline melanomzellen \\
\hline meningeome \\
\hline mikrokarzinom \\
\hline mischgliom \\
\hline morbus kahlermundhoehlenkarzinom \\
\hline multiple myelom \\
\hline mycosis fungoides \\
\hline myxofibrosarkom \\
\hline nasennebenhoehlentumor \\
\hline nasentumor \\
\hline nasopharynxkarzinom \\
\hline
\end{tabular}


medRxiv preprint doi: https://doi.org/10.1101/2021.03.25.21254314; this version posted March 26, 2021. The copyright holder for this preprint (which was not certified by peer review) is the author/funder, who has granted medRxiv a license to display the preprint in perpetuity.

\section{It is made available under a CC-BY-NC-ND 4.0 International license .}

\section{NLP COVID-19, Schöning (2021)}

\begin{tabular}{|c|}
\hline Key terms \\
\hline nebennierenkarzinom \\
\hline nebennierenneoplasie \\
\hline nebenschilddruesenkarzinom \\
\hline neoplasie \\
\hline neoplasieassoziert \\
\hline neoplasiebedingt \\
\hline neoplasiein \\
\hline neoplasien \\
\hline nephroblastom \\
\hline netzhauttumor \\
\hline neurinom \\
\hline neuroblastom \\
\hline nierenkarzinom \\
\hline nierenzellkarzinom \\
\hline nstmammakarzinom \\
\hline oesophaguskarzinom \\
\hline oligoastrozytome \\
\hline oligodendrogliome \\
\hline organmetastasen \\
\hline oropharynxkarzinom \\
\hline osteosarkom \\
\hline osteosarkom \\
\hline osteosarkomresektion \\
\hline ovarialkarzinom \\
\hline pankeasneoplasie \\
\hline pankreaskarzinom \\
\hline pankreaskopfkarzinom \\
\hline pankreaskopfneoplasie \\
\hline pankreaskorpuskarzinom \\
\hline pankreaskorpusneoplasie \\
\hline pankreasneoplasie \\
\hline pankreasschwanzkarzinom \\
\hline papillenkarzinom \\
\hline paraneoplasie \\
\hline peniskarzinom \\
\hline peritonealkarzinom \\
\hline peritonealkarzinomatose \\
\hline
\end{tabular}


medRxiv preprint doi: https://doi.org/10.1101/2021.03.25.21254314; this version posted March 26, 2021. The copyright holder for this preprint (which was not certified by peer review) is the author/funder, who has granted medRxiv a license to display the preprint in perpetuity.

\section{It is made available under a CC-BY-NC-ND 4.0 International license .}

\section{NLP COVID-19, Schöning (2021)}

\begin{tabular}{|l|}
\hline Key terms \\
\hline pharynxkarzinom \\
\hline plasmazellenneoplasie \\
\hline plasmazellmyelom \\
\hline plasmazellneoplasie \\
\hline plasmozytom \\
\hline plattenepithelkarzinom \\
\hline plattenepithelkarzinominfiltrate \\
\hline plattenepithelungenkarzinom \\
\hline plattenepithelzellkarzinom \\
\hline plexustumor \\
\hline primaerkarzinom \\
\hline primaertumor \\
\hline promyelozytenleukaemie \\
\hline prostatakarzinom \\
\hline prostatakrebs \\
\hline rachentumor \\
\hline rektumkarzinom \\
\hline retinoblastom \\
\hline rezidivurothelkarzinom \\
\hline rhabdomyomsarkom \\
\hline rhabdomyosarkomatoese \\
\hline samenblasenkarzinom \\
\hline sarkom \\
\hline sarkomatoes \\
\hline sarkomatoide \\
\hline sarkomgewebe \\
\hline sarkomresektion \\
\hline sarkomrezidiv \\
\hline sarkomrezidivresektion \\
\hline
\end{tabular}


medRxiv preprint doi: https://doi.org/10.1101/2021.03.25.21254314; this version posted March 26, 2021. The copyright holder for this preprint (which was not certified by peer review) is the author/funder, who has granted medRxiv a license to display the preprint in perpetuity.

\section{It is made available under a CC-BY-NC-ND 4.0 International license .}

\section{NLP COVID-19, Schöning (2021)}

\begin{tabular}{|l|}
\hline Key terms \\
\hline speicheldruesenkarzinom \\
\hline speiseroehrenkarzinom \\
\hline spinaliom \\
\hline spinalzellkarzinom \\
\hline stachelzellkarzinomstachelzellkarzinom \\
\hline stimmlippenkarzinom \\
\hline synovialsarkom \\
\hline thymon \\
\hline thymuskarzinom \\
\hline tonsillenkarzinom \\
\hline tritonskarzinoms \\
\hline tubenkarzinom \\
\hline unterleibskrebs \\
\hline urachuskarzinom \\
\hline urogenitalkarzinom \\
\hline urothelkarzinomrezidiv \\
\hline urothelkarzinomzellen \\
\hline uteruskarzinom \\
\hline uterussarkom \\
\hline uurothelkarzinom \\
\hline vaginalkarzinom \\
\hline vulvakarzinom \\
\hline weichteilsarkom \\
\hline wilmstumor \\
\hline zervixkarzinom \\
\hline zervixkarzinomnachsorge \\
\hline zoekumkarzinom \\
\hline
\end{tabular}

